\title{
Physical and geochemical properties of centennial marine sediments of the continental shelf of southeast Brazil
}

\author{
Anna Paula Soares Cruz ${ }^{1}$ \\ Cátia Fernandes Barbosa ${ }^{1 *}$ \\ Arthur Ayres-Neto \\ Ana Luiza Spadano Albuquerque ${ }^{1}$ \\ 'Departamento de Geoquímica Universidade \\ Federal Fluminense (UFF) - Niteroi (RJ), Brasil. \\ ${ }^{2}$ Departamento de Geologia e Geofísica, UFF - \\ Niteroi (RJ), Brasil. \\ *Corresponding author: catia@geoq.uff.br
}

\begin{abstract}
Studies associated with the physical properties of marine sediments are being increasingly disseminated around the world. Comparing these geophysical parameters with sedimentological analysis allows several correlations of the core collected in a region. This research combines sedimentological information of cores samples with geophysical and geochemical properties to identify the influence of organic matter and sediment texture on the characteristics and depositional dynamic. The sediment cores were collected using a box core in four stations of the mud facies from the Cabo Frio shelf, Brazil. Geophysical properties were acquired using the MSCL (multi-sensor core logger). The wave velocity, porosity, density, sediment texture, and organic content have been conducted in samples collected in the shelf mud. The physical properties helped to distinguish two groups, according to oceanographic and sedimentological patterns within the same depositional system. The first group was characterized by the presence of silty sand and high P-wave velocity (nearshore and offshore core) and the second group by the predominance of silt, high organic input, and porosity (the intermediate cores). The presence of coarser sediments in the first group indicates the contribution of terrigenous sediment carried by coastal currents. The second group presents the same deposition dynamic with high accumulation of fine particles and organic carbon, indicating the domain of high productivity upwelling currents and oceanic vortices.
\end{abstract}

Keywords: P-wave, grain size; porosity, organic carbon.

\section{Resumo}

Estudos relacionados às propriedades físicas de sedimentos marinhos estão aumentando em todo o mundo. A comparação de parâmetros geofísicos com análises sedimentológicas permite correlações entre testemunhos coletados em uma região. Esta pesquisa combina informações sedimentológicas de amostras de testemunhos com propriedades geofísicas e geoquimicas para identificar a influência da matéria orgânica e textura de sedimentos nas características e na dinâmica deposicional. Os testemunhos de sedimentos foram obtidos por meio de um coletor (box-core) em quatro estações da fácies de lama da plataforma de Cabo Frio, Rio de Janeiro, Brasil. As propriedades geofísicas foram adquiridas usando-se o MSCL (amostrador de testemunho multissensor, do inglês multi-sensor core logger). Dados sobre velocidade de ondas, porosidade, densidade, textura do sedimento e teor de matéria orgânica foram obtidos das amostras coletadas na fácies de lama. As propriedades físicas ajudaram a distinguir dois grupos, de acordo com os padrões oceanográficos e sedimentológicos, dentro do mesmo sistema deposicional. O primeiro grupo é caracterizado pela pre- 
sença de areia com silte, e velocidade alta das ondas P (próxima e longe da costa); o segundo grupo caracteriza-se pela predominância de silte, entrada alta de material orgânico e porosidade (testemunhos intermediários). A presença de sedimentos mais grossos no primeiro grupo indica a contribuição de sedimentos terrígenos carregados por correntes costeiras. O segundo grupo apresenta a mesma dinâmica de deposição com alta acumulação de partículas finas e carbono orgânico, indicando predominância de correntes upwelling de alta produtividade e vórtices oceânicos.

Palavras-chave: onda-P, tamanho do grão, porosidade, carbono orgânico.

\section{INTRODUCTION}

The physical properties of marine sediments have been widely used to understand the geological events as good indicators for the composition, microstructure, and environmental conditions during and after the depositional process (Kim et al. 2001). Besides physical properties, geochemical processes indicate the source of the sediments and thus provide insights into changes in transport and sedimentation processes.

The combination of physical and chemical properties enables the evaluation of the processes involved throughout the sedimentary profile, allowing the determination of environmental changes (Schulz \& Zabel, 1999). In marine sediments, physical parameters are important to quantify the amount and distribution of pore space and diagenesis process (Wagner et al. 2004), of which the porosity is used for determine the flow, indicating the fluid permeability, and the modification by post depositional processes.

Depositional processes play the primary role in determining the nature and spatial distribution of sea floor sediments and can be influenced by factors such as geological setting, sediment supply, and ocean flux (Davis et al. 2002).

The amount of total organic carbon (TOC) and changes in element composition, grain size, gamma-density, porosity,

\subsection{Coastal setting}

Cabo Frio continental shelf is located on the east coast of Rio de Janeiro State, Brazil (latitude 23 ${ }^{\circ} 11^{\prime} \mathrm{S}$ and longitude $\left.42^{\circ} 47^{\prime} \mathrm{N}\right)$. This area is characterized by a coastal upwelling system controlled by physiographic, oceanographic, and atmospheric factors (Valentin 1984). Additionally, this shelf presents distinct sedimentological and oceanographic properties due to the change in coastline orientation (Figure 1). In the southern portion of Cabo Frio, where the shelf break is deeper, the accumulation of muddy sediments occur predominantly, while the northern portion, where the break is shallower, is composed of sediments consisting of carbonate minerals (Mahiques et al. 2005).

Based on the composition of surface sediments of the continental shelf of Cabo Frio, Dias et al. (1990) showed that the sedimentary distribution is dominated by fine sand and there is a mud facies, consisting of clay and silt in the deeper areas. Saavedra et al. (2009) analyzed the mineralogy and p-wave can be used as indicators of past environmental changes (Schulz \& Zabel, 1999). According to Ayres-Neto (1998), the use of isolated techniques does not provide concrete evidence on sedimentary characteristics. Thus, coupling physical and sediment methods can be used for modeling the geoacoustic of the seafloor, being applied to the characterization of the seabed and mineral prospecting (Macedo et al. 2009).

The southern Brazilian shelf presents sedimentation dominated by the dynamic of oceanic water masses, which determine primary productivity and sediment redistribution on the shelf, leading to the establishment of differences in sedimentation rates and sedimentary profiles (Mahiques et al. 2010). In Cabo Frio, southeastern Brazil, the likely interaction between the upwelling events and vortices favors the high productivity and sedimentation rates locally.

Thus, this paper has the objective of evaluating the variation of physical properties along the mud facies, performing comparison between the analyzed cores, in order to identify the influence of organic matter and sediment texture on the characteristics and depositional dynamic associate with the study area.

of the suspended sediments of Cabo Frio and noted strong evidence of the contribution of the Paraiba do Sul River and the Guanabara Bay in the formation of the mud facies, where bottom currents carry the material toward the coast and toward the north and surface flows to SW and W.

Regions influenced by deep water upwelling, which are cold and rich in nutrients, are known by their high biological productivity (Valentin 1994). This event occurs by the change of the Brazil Current (BC), which moves away from the coast due to winds predominantly from the NE which favors upwelling of South Atlantic Central Water (SACW), present at pycnocline levels (Mahiques et al. 2007). This process can be explained by Ekman transport (Franchito et al. 1998), which generates a perpendicular flow promoting the removal of the surface water mass due to the rotation of the Earth (Coriolis effect). This upwelling of SACW, cold and rich in nutrients, is the main source of nutrients for primary production. 
Furthermore, Mascarenhas et al. (1971) described the presence of cyclonic and anticyclonic vortices in the region off Cabo Frio due to the change in orientation of the coastline and the gradient of bottom topography. Thus, it is expected that the $\mathrm{BC}$, flowing along the shelf break, partially change its direction and heads out to

\section{MATERIAL AND METHODS}

The sediment cores were collected using a box core between April 24 and May 3, 2010, on the board of the vessel AV.Pq.Oc. Diadorim of the Instituto de Estudos do Mar Almirante Paulo Moreira - IEAPM/Navy of Brazil. PVC core tubes (diameter of $100 \mathrm{~mm}$ and length about $30 \mathrm{~cm}$ ) were inserted into the sediment, in four stations of the mud facies between 80 and $140 \mathrm{~m}$ water depth on the Cabo Frio shelf (Table 1). These cores were identified according to their location, being the offshore core BCCF10-01, the intermediated cores identified as BCCF10-04 and BCCF10-09, and the nearshore identified as BCCF10-13 (Figure 1, Table 1).

In the laboratory, the cores were examined using a multi-sensor core logger (MSCL) that is a system for logging physical properties of sediment cores at small sampling intervals (Best \& Gunn 1999). The sediment cores were analyzed every $0.5 \mathrm{~cm}$ with $250 \mathrm{kHz}$ of the frequency, where the physical parameters analyzed were the compressional wave velocity, gamma-density, and porosity. In order to avoid deeper waters (offshore). Campos et al. (2000) propose that the $\mathrm{BC}$ cyclones may induce upwelling of shelf break, bringing SACW to coastal regions. This mechanism of upwelling of SACW over the continental shelf is independent of the season and is not restricted to the austral summer (Silveira et al. 2000).

errors during the analysis of gamma-density, the calibration was done according to Best \& Gunn (1999).

Sampling of sediment cores were done by extrusion of slices of $1 \mathrm{~cm}$ thickness and the samples were stored in a plastic bag at $+4^{\circ} \mathrm{C}$ for further analysis. In the laboratory, each sample was divided into subsamples and then decarbonated using $\mathrm{HCl}(1 \mathrm{~N})$ to determine the grain size and TOC.

The grain-size measurements were performed using the laser particle analyzer CILAS 1064, which has detection range of $0.02-2000 \mu \mathrm{m}$. The grain-size classification was done according to Folk and Ward (1957) using the method of size scale adopted in the GRADISTAT software (Blott $\&$ Pye 2001). The samples for TOC were dried at $40^{\circ} \mathrm{C}$ for $48 \mathrm{~h}$ and about $0.01 \mathrm{~g}$ of each sample was crushed, which were inserted in tin capsules and sent to Stable Isotopes Laboratory of the University of California at Davis (USA). The analysis was performed using an automatic analyzer
Figure 1

Location of coring sites along the Cabo Frio continental shelf.
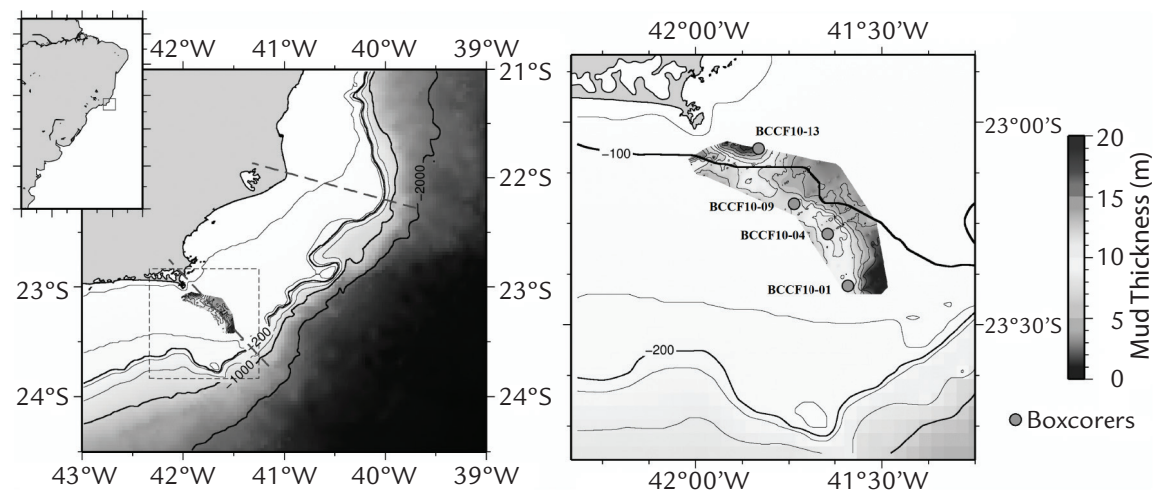

Table 1

Position of core stations (Latitude/Longitude, Water Depth $(\mathrm{m})$, Core Recover $(\mathrm{cm})$, and Sedimentation Rate (cm/year).

\begin{tabular}{cccccc}
\hline Core & Latitude & Longitude & $\begin{array}{c}\text { Water } \\
\text { Depth }(\mathbf{m})\end{array}$ & $\begin{array}{c}\text { Core } \\
\text { Recover } \\
(\mathbf{c m})\end{array}$ & $\begin{array}{c}\text { Sedimentation } \\
\text { Rate }(\mathbf{c m} / \text { year })\end{array}$ \\
\hline BCCF10-01 & $-23^{\circ} 40^{\prime} 38^{\prime \prime}$ & $41^{\prime} 59^{\prime} 01^{\prime \prime}$ & 141 & 15 & 0.11 \\
BCCF10-04 & $-23^{\circ} 27^{\prime} 64^{\prime \prime}$ & $41^{\circ} 64^{\prime} 98^{\prime \prime}$ & 113 & 22 & 0.14 \\
BCCF10-09 & $-23^{\circ} 20^{\prime} 13^{\prime \prime}$ & $41^{\circ} 73^{\prime} 63^{\prime \prime}$ & 108 & 21 & 0.18 \\
BCCF10-13 & $-23^{\circ} 06^{\prime} 51^{\prime \prime}$ & $41^{\circ} 83^{\prime} 17^{\prime \prime}$ & 87 & 11 & 0.32 \\
\hline
\end{tabular}


CHNS LECO coupled with mass spectrometer. The results were expressed in percentage (\%).

The chronology and the sedimentation rates were determined by using the ${ }^{210} \mathrm{~Pb}$ activity based on decay of the ${ }^{238} \mathrm{U}$ series following the method described by Moore (1984) and

\section{RESULTS}

The sediment of the study area is composed of silt. The texture of this muddy facies is heterogeneous and differs by

\subsection{Core BCCF10-01}

The offshore box core BCCF10-01 recovered $15 \mathrm{~cm}$ of sediment and is composed of more than $60 \%$ of coarse silt with the average grain size ranging from 4.8 to $6.2 \varphi$ averaging $5.3 \varphi$. This core presented two textures, the silty-sandy facies between 0 and $5 \mathrm{~cm}$, with a predominance of fine sand, with an average grain size of $5.0 \varphi$. Sandy silt facies occurred between 5 and $15 \mathrm{~cm}$ composed of coarse silt with mean grain size of $5.4 \varphi$ (Table 2). The sedimentation rate estimated for this core was $0.1 \mathrm{~cm} /$ year, obtaining records from the last 150 years before present (BP) (Table 1).

The P-wave values for this core ranged from $1516 \mathrm{~m} / \mathrm{s}$ to $1527 \mathrm{~m} / \mathrm{s}$ (average $1521 \mathrm{~m} / \mathrm{s}$ and standard deviation of $3.20 \mathrm{~m} / \mathrm{s}$ ). analyzed by Sanders et al. (personal communication 2013). The sedimentation rate was calculated by the decay curve in relation to depth, providing an age-depth model for the last 150 years, being extended to the base of the box cores to estimate the historic age of the sedimentary deposits.

the sand content and the different depositional processes that occur in the region.

The silty sand portion presents the propagation velocity mean values of $1523 \mathrm{~m} / \mathrm{s}$, while in the sandy silt portion the propagation velocity was $1519 \mathrm{~m} / \mathrm{s}$. The porosity data ranged from $55 \%$ to $65 \%$ with an average of $63 \%$ and standard deviation of $1.1 \%$. In this core, the porosity decreases from the bottom to $8 \mathrm{~cm}$ and a further reduction from $8 \mathrm{~cm}$ to the top of the core (Figure 2). The gamma-density showed a specular image of the porosity, ranging from 1.62 to $1.71 \mathrm{~g} / \mathrm{cm}^{3}$, with an average of $1.65 \mathrm{~g} / \mathrm{cm}^{3}$ and standard deviation of $0.19 \mathrm{~g} / \mathrm{cm}^{3}$ (Figure 2). The TOC values were between 0.61 and $1.74 \%$ (average $1.18 \%$ and standard deviation of $0.32 \%$ ) and water content for this core varied from 29 to $38 \%$ (average $34 \%$ and standard deviation of $1.8 \%$ ).

\begin{tabular}{|c|c|c|c|c|c|c|c|c|c|}
\hline نั & 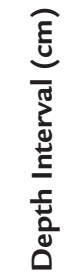 & 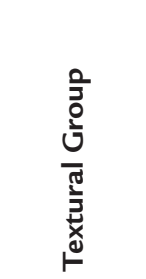 & 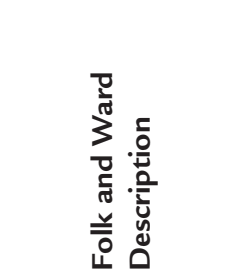 & 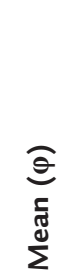 & $\begin{array}{l}\text { ज } \\
\text { E} \\
0 \\
0 \\
3 \\
\vdots \\
0\end{array}$ & 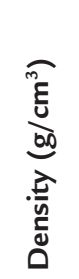 & $\begin{array}{l}\frac{0}{0} \\
\frac{1}{4} \\
\frac{0}{0} \\
0\end{array}$ & 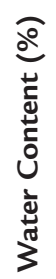 & $\frac{\overparen{\varrho}}{\stackrel{\varrho}{\varrho}}$ \\
\hline \multirow{2}{*}{ BCCF10-01 } & $0-5$ & Silty Sand & Very Fine Sand & 5.06 & 1523 & 1.65 & 64 & 34 & 1.15 \\
\hline & $5-15$ & Sandy Silt & Coarse Silt & 5.41 & 1519 & 1.66 & 63 & 33 & 1.20 \\
\hline BCCF10-04 & $0-22$ & Silt & Medium/Fine Silt & 6.70 & 1495 & 1.62 & 65 & 43 & 1.77 \\
\hline BCCF10-09 & $0-21$ & Silt & Medium/Fine Silt & 6.63 & 1403 & 1.52 & 71 & 48 & 1.65 \\
\hline \multirow{3}{*}{ BCCF10-13 } & $0-6$ & \multirow{3}{*}{ Sandy Silt } & Coarse Silt & 5.43 & 1518 & 1.57 & 68 & 42 & 1.09 \\
\hline & $7-8$ & & Medium Silt & 6.34 & 1503 & 1.71 & 60 & 40 & 0.75 \\
\hline & $9-11$ & & Coarse Silt & 5.62 & 1510 & 1.72 & 59 & 36 & 1.07 \\
\hline
\end{tabular}

\section{Table 2}

Description of the core showing the textural and Folk and Ward group, mean grain size $(\varphi)$, P-wave velocity $(\mathrm{m} / \mathrm{s})$, density $\left(\mathrm{g} / \mathrm{cm}^{3}\right)$, porosity $(\%)$, water content (\%), and total organic carbon (\%) for each depth intervals $(\mathrm{cm})$.

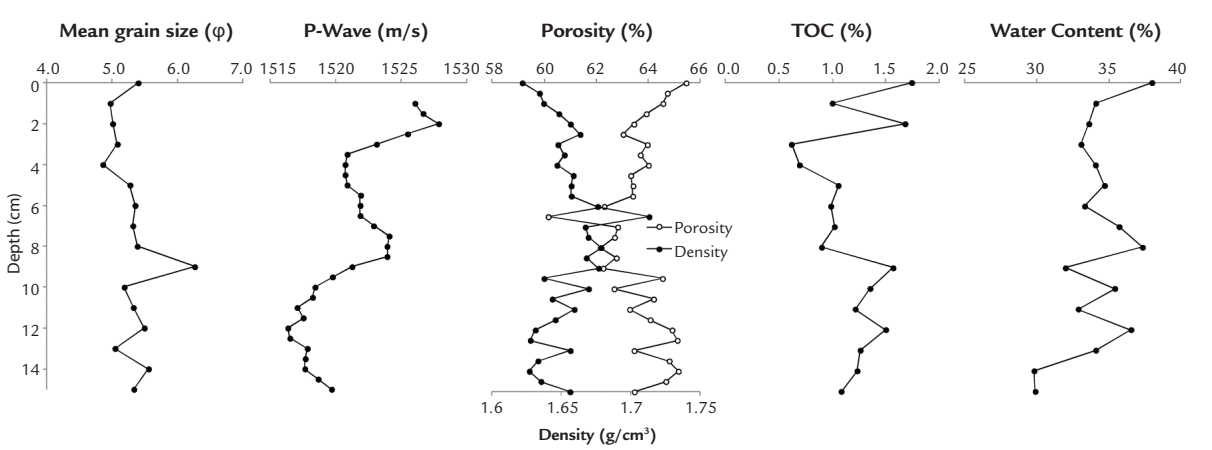

Figure 2

Means grain size $(\varphi)$, P-wave velocity $(\mathrm{m} / \mathrm{s})$, density $\left(\mathrm{g} / \mathrm{cm}^{3}\right)$, porosity $(\%)$, total organic carbon (\%), and water content (\%) profiles for BCCF10-01 core. 


\subsection{Core BCCF10-04}

The core BCCF10-04 located in the central area of the mud facies recovered $22 \mathrm{~cm}$ of sediment, consisting predominantly of fine particles, ranging from medium to fine silt. The average grain size for this core varied from 5.6 to $8.0 \varphi$ with an average of $6.7 \varphi$, presenting silty texture (Table 2 ). The sedimentation rate was estimated at $0.14 \mathrm{~cm} /$ year, obtaining records of 157 years $\mathrm{BP}$ (Table 1 ).

The $\mathrm{P}$-wave values ranged from 1485 to $1504 \mathrm{~m} / \mathrm{s}$ (average $1495 \mathrm{~m} / \mathrm{s}$ and standard deviation of $5.5 \mathrm{~m} / \mathrm{s}$ ). This core presented lower P-wave values when compared with BCCF10-01. The porosity data ranged from 53 to $74 \%$ with an average of $65 \%$ and standard deviation of $5.2 \%$. Porosity values along the core presented few oscillations increasing toward the top. The gamma-density ranged from 1.4 to $1.8 \mathrm{~g} / \mathrm{cm}^{3}$ with a mean of $1.6 \mathrm{~g} / \mathrm{cm}^{3}$ and standard deviation of $0.08 \mathrm{~g} / \mathrm{cm}^{3}$ (Figure 3).

The content of TOC for this core varied from $1.4 \%$ to $2.1 \%$ (average $1.7 \%$ and standard deviation of $0.15 \%)$. These values were kept constant with high values throughout the core. The water content varied between $37 \%$ and $48 \%$ (average of $43 \%$ and standard deviation of $3.3 \%$ ), increasing toward the top (Figure 3).
Figure 3

Mean grain size $(\varphi)$, P-wave velocity $(\mathrm{m} / \mathrm{s})$, density $\left(\mathrm{g} / \mathrm{cm}^{3}\right)$, porosity (\%), total organic carbon (\%), and water content (\%) profiles for BCCF10-04 core.
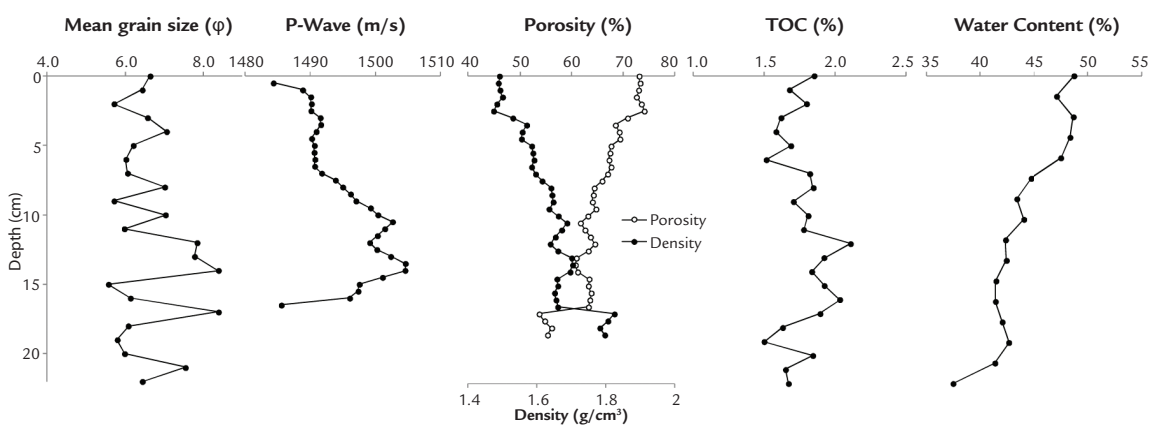

\subsection{Core BCCF10-09}

The core BCCF10-09, located in the central area of the mud facies, recovered $21 \mathrm{~cm}$ of sediment, consisting of fine particles, ranging from medium to fine silt. The average grain size for this core varied from 5.9 to $7.7 \varphi$ with an average of $6.6 \varphi$ and silty texture (Table 2). The sedimentation rate estimated for this core was $0.18 \mathrm{~cm} / \mathrm{year}$, obtaining records of 117 years BP (Table 1 ).

The P-wave values for this core ranged from 1400 to $1404 \mathrm{~m} / \mathrm{s}$ (average of $1403 \mathrm{~m} / \mathrm{s}$ and standard deviation of $0.9 \mathrm{~m} / \mathrm{s}$ ), obtaining the lowest P-wave between the analyzed cores.

The acoustic propagation near the top and the base of the cores analyzed was below the benchmark of P-wave, even with no debris that could cause the scattering of the signal. This was due to the proximity to the seal cap which may have caused the loss of water in the sample (Figure 4).

The porosity values ranged from 65 to $77 \%$ with an average of $71 \%$ and standard deviation of $3.9 \%$, increasing their values along the profile. The gamma-density values ranged from 1.41 to $1.62 \mathrm{~g} / \mathrm{cm}^{3}$ with an average of $1.52 \mathrm{~g} / \mathrm{cm}^{3}$ and standard deviation of $0.06 \mathrm{~g} / \mathrm{cm}^{3}$ (Figure 4).

The content of TOC ranged from 0.88 to $2.36 \%$ (average $1.6 \%$ and standard deviation of $0.32 \%$ ) and water content ranged from 39 to $57 \%$ (average $48 \%$ and standard deviation $4.3 \%$ ) (Table 2 ).
Figure 4

Mean grain size $(\varphi)$, P-wave velocity $(\mathrm{m} / \mathrm{s})$, density $\left(\mathrm{g} / \mathrm{cm}^{3}\right)$, porosity (\%), total organic carbon (\%), and water content (\%) profiles for BCCF10-09 core.

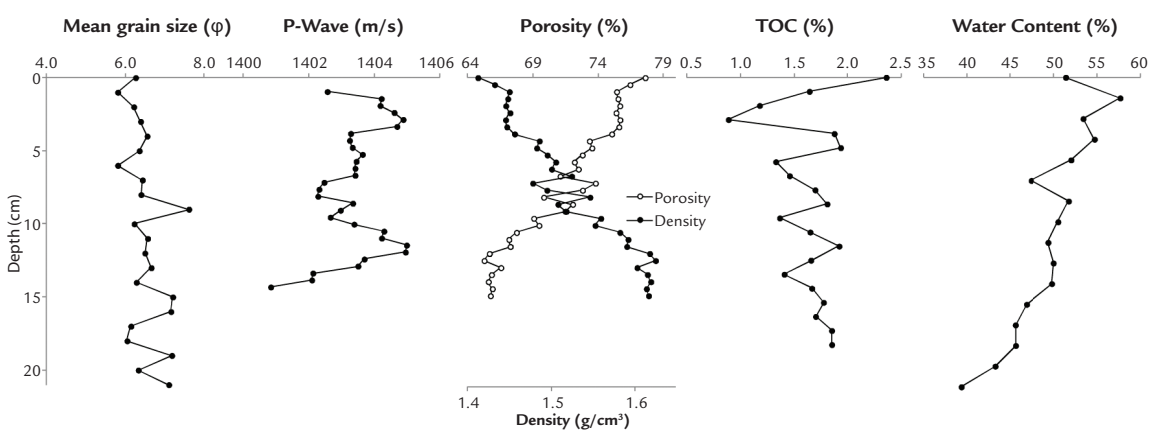




\subsection{Core BCCF10-13}

The nearshore core BCCF10-13 recovered $11 \mathrm{~cm}$ of sediment, in which $80 \%$ of the core presented coarse silt with recovered $11 \mathrm{~cm}$, having predominantly coarse particles, approximately $80 \%$ of the core presented coarse silt with grain size ranging from 5.0 to $5.6 \varphi$ and $20 \%$ of medium silt with an average of $6.3 \varphi$ (Table 2). The sedimentation rate for this core was calculated as $0.31 \mathrm{~cm} /$ year, recording 34 years $\mathrm{BP}$ (Table 1 ).

High P-wave values were present throughout the core, ranging from 1454 to $1525 \mathrm{~m} / \mathrm{s}$ (average $1511 \mathrm{~m} / \mathrm{s}$ and standard deviation of $19.8 \mathrm{~m} / \mathrm{s}$ ). Gamma-density values for core BCCF10-13 ranged from 1.51 to $1.74 \mathrm{~g} / \mathrm{cm}^{3}$ (average $1.61 \mathrm{~g} / \mathrm{cm}^{3}$ and a standard deviation of $\left.0.07 \mathrm{~g} / \mathrm{cm}^{3}\right)$, decreasing toward the top. The porosity data ranged from $58 \%$ to $71 \%$ with an average of $65 \%$ and standard deviation of 4.6 (Figure 5).

The TOC showed lower values than the other cores, ranging from 0.6 to $1.3 \%$ (average $1.02 \%$ and standard deviation of $0.18 \%$ ). The water content ranges from 35 to $45 \%$ (average $39.9 \%$ and standard deviation of $3.4 \%$ ) (Figure 5).

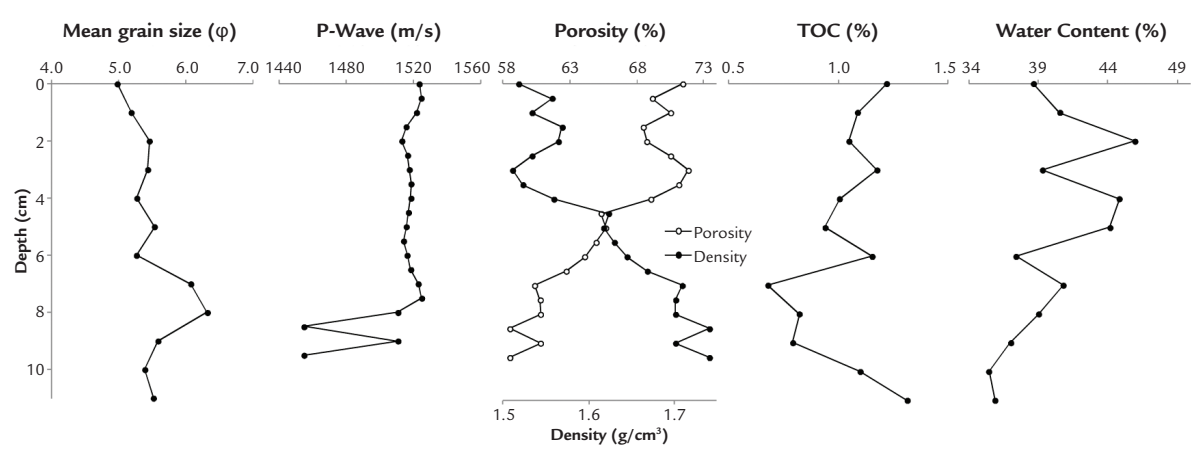

Figure 5

Mean grain-size $(\varphi)$, P-wave velocity $(\mathrm{m} / \mathrm{s})$, density $\left(\mathrm{g} / \mathrm{cm}^{3}\right)$, porosity $(\%)$, total organic carbon (\%), and water content (\%) profiles for BCCF10-13 core.

\subsection{Relation between the physical properties of sediments}

The relation between the physical properties of sediments may show a little overview of the sedimentary environment in which the sediment was deposited. The $\mathrm{P}$-wave velocity showed a significant correlation with mean grain size $(p>0.05, r=-0.48)$ (Figure 6$)$. The relation between $\mathrm{P}$-wave and porosity showed a negative correlation $(\mathrm{r}=-0.62)$, indicating that the higher the porosity the lower the P-wave (Figure 6). The porosity is defined as the volume of the void filled with water; thus, the relationship between water content and P-wave follows the same pattern as set forth above, obtaining a negative correlation $(\mathrm{r}=-0.75)$, in which the increased content of water, due to the increased porosity of the material, promotes the reduction of P-wave (Figure 6).
The water content of the sediment has a strong correlation with the sediment porosity, obtaining a positive correlation ( $r=0.77)$. Thus, finer sediments (as clays) have a higher capacity of liquid retention, which makes the relationship between water content and average grain size positive $(\mathrm{r}=0.51)$ (Figure 6).

The organic carbon has a profound effect on the physical properties of the sediment, which can adhere to fine grains, such as clay, and increasing the capacity of water absorption of the material. Thus, the TOC ratio and average grain size are positive correlated $(\mathrm{r}=0.62)$, being higher when the grain size decreases. A positive correlation is also observed between TOC and water content $(\mathrm{r}=0.34)$ (Figure 6). 

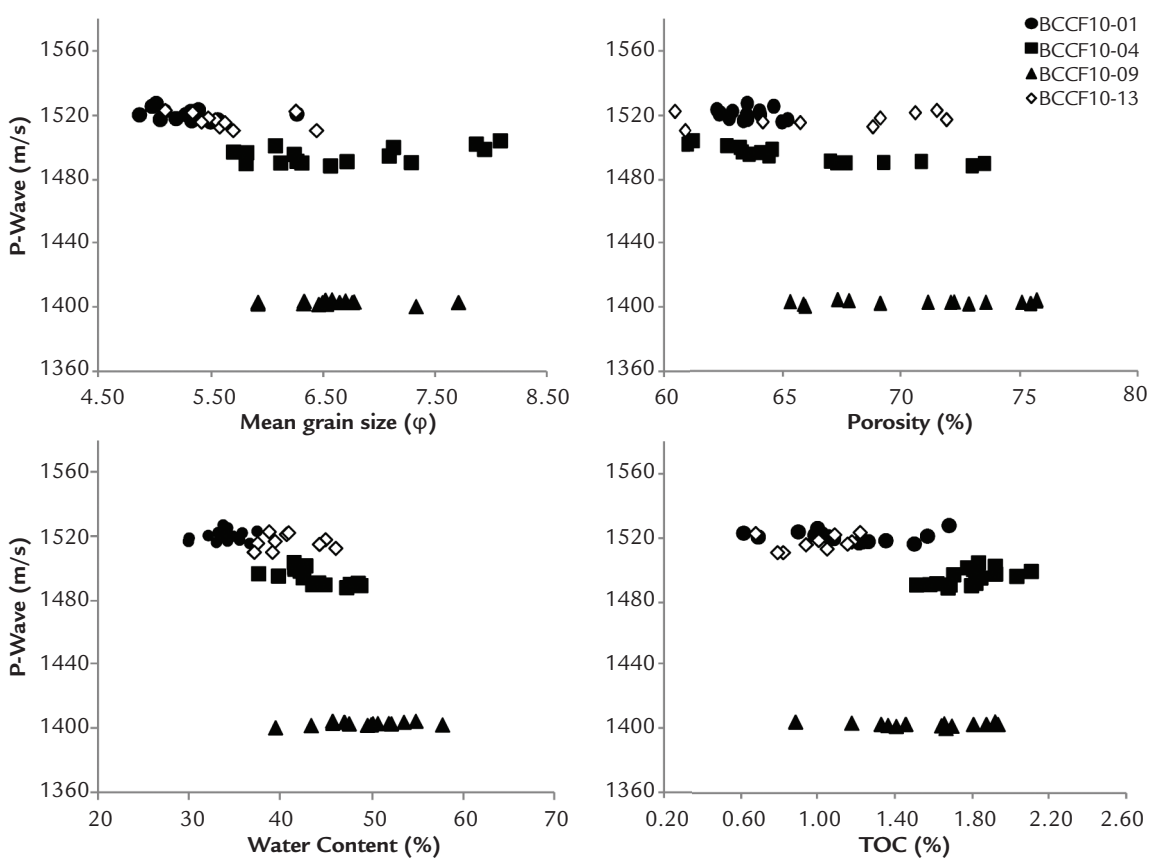

Figure 6

Relation between the physical properties for all the samples analyzed.
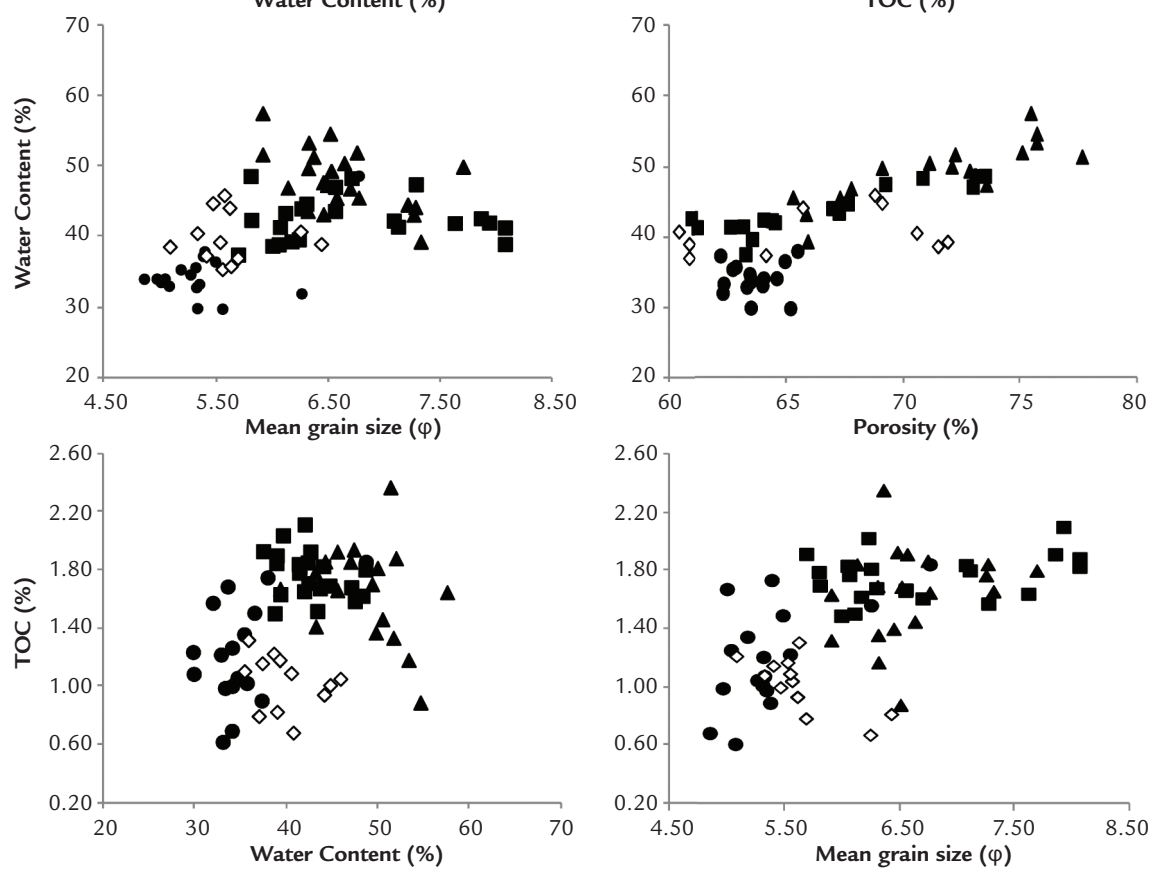

\section{DISCUSSION}

\subsection{P-wave profiles}

P-wave profile varies according to the sediment type. The records of the highest values of $\mathrm{P}$-wave velocity occurred in coarser textures (BCCF10-01 and BCCF10-13), while sediments containing silt and clay (BCCF10-04 and BCCF10-09) showed lower propagations velocities. Similar behavior was found by Hamilton (1979) and Kim et al. (2001), showing high velocities (1500 to $1600 \mathrm{~m} / \mathrm{s}$ ) on coarser textures. In upwelling systems as in California, Wang et al. (1995) showed that the variation of $\mathrm{P}$-wave with the grain size is due to difference in geoacoustic energy of the sediments. Thus, layers with high silt content have lower geoacoustic energy than homogeneous sandy-silt layers.
The cores with lower water content and higher grain size (Table 2), as BCCF10-01 and BCCF10-13, have a wide range of $\mathrm{P}$-wave velocity, while sediments with higher concentrations of water and fine texture are homogeneous and less susceptible to changes in its propagation. The sound propagation velocity in seawater is around $1400 \mathrm{~m} / \mathrm{s}$; thus, the greater the water content the lower the P-wave velocity (Figure 6) (Hamilton 1979). Thus, the grain size and water content determine the acoustic properties of marine sediment through changes in density and porosity of the material (Kim et al. 2001). 


\subsection{Porosity}

In marine sediment, porosity may vary from $35 \%$ to $90 \%$ (Hamilton \& Bachmann 1982). In upwelling systems, such as the Peru-Chile, the porosity is strongly affected by the organic content due to the high productivity, which provides an increase in water content of sediment (Brusch \& Keller 1981).

The presence of clay in marine sediment also facilitates the water retention, as they may be flocculated by electrolytes, adsorbing ions, and organic matter, making them more plastic (Krauskopf KB 1972). Therefore, clays can affect the electrical balance of sediment absorbing water and changing the degree of sediment consolidation (Hamilton 1970). Thus, on fine grain cores (BCCF10-04 and BCCF10-09) P-wave propagation tend to slow down (Figure 6), due to the increase of water content and low elastic compression of the sediment (Maa et al. 1997).

In upwelling areas, the abrupt reduction in the $\mathrm{P}$-wave propagation is due to the change in the degree of consolidation generated by the local dynamic (Mienert \& Schultheiss 1989). Despite the proximity of cores and similar texture, the BCCF10-04 presents

\subsection{Organic Carbon}

In marine sediments, the accumulation of organic carbon is dependent on the productivity, microbial degradation rate, and the oceanographic conditions (Barcellos $\&$ Furtado 1999). Permanent pycnocline has been considered recently as important component holding more than $50 \%$ of carbon release to the atmosphere, in centennial timescale (Wakelin et al. 2012). In upwelling regions, the pycnocline dynamic oscillation may be responsible for the high carbon contribution to the sediment. The increase in the accumulation rate may also occur by the proximity of coastal areas, particularly in regions where there is upwelling of deep waters (Brusch \& Keller 1982). Thus, in Cabo Frio, a synergy can occur between the oscillation of pycnocline, due the SACW upwelling, and the proximity to the coast favoring the accumulation of carbon mainly in the more central sites of the shelf.

The organic carbon content is a good indicator of the abundance of organic matter in marine sediments (Meyers 1997, 2003), being associated with fine sediment. The or-

\subsection{Regional Dynamic}

Comparing the cores of the mud facies, a separation of areas with different sediment input and dynamics was porosity and water content lower than BCCF10-09. This may occur due to the lower sedimentation rate found in BCCF10-04, which results in high compaction and low water absorption.

In BCCF10-01, low porosity between 15 and $8 \mathrm{~cm}$ occurs predominantly by fine particles mixed with fine sand. The spaces between sand grains are filled by silt and clay (abundant in the study area), reducing the porosity due the decrease of the pore spaces. However, from $8 \mathrm{~cm}$ to the top, the presence of sand makes the water enter easily between the grain, increasing the permeability and therefore porosity. The BCCF10-13 presents sand texture along the profile, which also shows this increase in porosity from bottom to the top (Figure 5). Furthermore, high sedimentation rate hinders the consolidation of the sediment, resulting in high water content and porosity, particularly in the upper layers.

Thus, high water content and porosity are associated with the texture of grains and the presence of organic matter can influence on sediment consolidation as proposed by Busch \& Keller (1981) for the Peru-Chile upwelling system as also observed in Cabo Frio upwelling system.

ganic matter combined with clay and/or mineral particles decreases its exposure time to degradation in the water column, promoting good preservation in the sediment (Mccave 1984). This association of fine texture with the organic content can be observed in the cores BCCF1004 and BCCF10-09, which have a predominance of fine grains and high organic carbon content (Figure 6). The organic matter adhered to the fine grains allows greater absorption of water, affecting the structure and the consolidation of the sediments, due to the change in porosity and density. Furthermore, the interaction between organic carbon and the ability in absorption of water may explain the lower values of P-wave velocity in the core BCCF10-09.

These central cores have values of organic carbon $50 \%$ greater than the BCCF10-01 and BCCF $10-13$. The lower carbon content observed on the inner and outer cores may be associated with high sedimentation rates (Tyson 1995) and grain-size difference (Hass \& van Weering 1997) as well as hydrodynamics of the area. noticed. The cores BCCF10-04 and BCCF10-09 (Table 2), located in the central portion, showed lower P-wave average 
than the cores BCCF10-01 and BCCF10-13. This differentiation indicates different oceanographic and sedimentological regimes within the same depositional system.

The horizontal transport of particles is generated by the current offset, which promotes zones of preferential deposition. The shape, size, and weight of particles determine their residence time in the water column and the transport type. Thus, fine particles are transported in suspension move away from the coast, being redistributed by a regional scale current (Muehe \& Carvalho 1993). Thus, the decrease in sediment grain size with the increasing coastal distance can be related to the lower energy influx on the seafloor. However, on the inner shelf of Cabo Frio, the sedimentation is mainly determined by the Brazilian Coastal Current (Souza \& Robinson 2004), which is NS oriented; the continental shelf allows this current to move closest to the coast. The sedimentary processes on the outer shelf are influenced by BC, which flows south- ward along shelf (Mahiques et al. 2002, 2004) due to the bathymetry and the coastline orientation changes (E-W), which contribute to the formation of meanders of the BC.

The grain size distribution and $\mathrm{P}$-wave velocity throughout the sedimentary facies show the depositional dynamic, in which the sediments are transported by coastal currents promoting highest accumulation rate at BCCF10-13 site. The coastal current bifurcates due to the abrupt change of the coastline (N-S to E-W) transporting these sediments for outer shelf, which are deposited on the BCCF10-01 site. However, the domain of upwelling currents and oceanic vortices in this region (Wakelin et al. 2012) may also contribute to the increase in primary production in the water column and a quickly and efficient export of these particles to sediments (Carreira et al. 2012). Thus, the high carbon deposition, mainly on the middle shelf, is derived from autochthonous production, with a minor contribution from continental drainage.

\section{CONCLUSION}

Through the physical properties of the sediment deposited on centennial time scale, it was possible to separate the four cores in two groups. The first group consists of the inner and outer shelf cores, which are characterized by the presence of silty sand and high P-wave velocity. The second group, formed by the mid-shelf cores, is characterized by the predominance of silt, high organic input, and porosity. The presence of coarser sediments in the first group indicates the contribution of terrigenous sediment. This material is potentially carried by coastal currents that promote the deposition preferably nearshore. Furthermore, the abrupt change of the coast line (N-S for E-W) promotes the bifurcation of coastal current, causing offshore deposition.

\section{ACKNOWLEDGMENTS}

We thank Upwelling project (Petrobras geochemistry network) and the crew of the Diadorim vessel for
However, the samples of the second group (cores BCCF10-04 and BCCF10-09) due to the proximity between them present the same deposition dynamic. They were characterized by high accumulation of fine particles, high water content, low P-wave velocity, and high organic carbon. These records are typical of upwelling areas that cause the pycnocline instability promoting the high carbon deposition, with an increase in autochthonous production and with a minor contribution from continental drainage.

This pattern can also be seen in other upwelling systems such as Peru-Chile and Oman, where the accumulation of organic material and fine grains influence on the sediment deposits resulting from changes in oceanographic dynamic.

the sampling. Rodrigo Abuchacra helped in core logger physical analysis.

\section{REFERENCES}

Ayres-Neto A. 1998. Relationships between physical properties and sedimentological parameters of near surface marine sediments and their applicability in the solution of engineering and environmental problems. PhD Thesis, University of Kiel, Germany, 126 pp.

Barcellos R.L. \& FurtadoV.V. 1999. Processo sedimentar atual e a distribuição de carbono e nitrogênio orgânicos no Canal de São Sebastião (SP) e plataforma interna adjacente. Revista Brasileira de Oceanografia, 47(2):207-221.

Best A.I. \& Gunn D.E. 1999. Calibration of marine sediments core logger for quantitative acoustic impedance studies. Marine Geology, 160(1-3):137-146.

Blott S.J. \& Pye K. 2001.Gradistat: a grain size distribution and statistics package for the analysis of unconsolidated sediments. Earth Surface Processes and Landforms, 26:1237-1248. 
Busch W.H. \& Keller G.H. 1981. The physical properties of Peru-Chile continental margin sediments - the influence of coastal upwelling on sediment properties. Journal of Sedimentary Petrology, 51(3):705-719.

Brusch W.H. \& Keller G.H. 1982. Consolidation characteristics of sediments from the Peru-Chile continental margin and implications for past sediment instability. Marine Geology, 45:17-39.

Campos E.J.D., Velhote D., Silveira I.C.A. 2000. Shelf breaks upwelling driven by Brazil Current cyclonic meanders. Geophysical Research Letters, 27:751-754.

Carreira R.S., Canuel E.A., Macko S.A., Lopes M.B., Luz L.G., Jasmim L.N. 2012. On the accumulation of organic matter on the southeastern Brazilian continental shelf: a case study based on a sediment core from the shelf off Rio de Janeiro. Brazilian Journal of Oceanography, 60(1):75-87.

Davis A., Haynes R., Bennell J., Huws D. 2002. Surficial seabed sediment properties derived from seismic profiler responses. Marine Geology, 182:209-223.

Dias J.L., Scarton J.C., Guardado L.R., Esteves F.R., Carminatti M. 1990. Aspectos da evolução tectono-sedimentar e a ocorrência de hidrocarbonetos na Bacia de Campos. In: G.P. Raja Gabaglia \& E.J. Milani (eds.) Origem e Evolução de Bacias Sedimentares, Petrobras: 333-360.

Folk R.L. \& Ward W.C. 1957. Brazos River bar: a study in the significance of grain size parameters. Journal of Sedimentary Petrology, 27:3-26.

Franchito S.H., Rao V. B., Stech J. L., Lorenzzetti J. A. 1998. The effect of coastal upwelling on the sea-breeze circulation at Cabo Frio, Brazil: a numerical experiment. Annales Geophysicae, 16:866-881.

Hamilton, E.L., 1970. Elastic properties of marine sediments. Journal of Geophysical Research, 76:579-604.

Hamilton E.L. 1979. Sound velocity gradients in marine sediments. Journal of the Acoustical Society of America, 65:909-922.

Hamilton E.L. \& Bachman R.T. 1982. Sound velocity and related properties of marine sediments. Journal of the Acoustical Society of America, 72:1891-1904.

Hass H. \& van Weering T.C.E. 1997. Recent sediment accumulation, organic carbon burial and transport in the northeastern North Sea. Marine Geology, 136:173-187.

Kim D.C., Sung J.Y., Park S.C., Lee G.H., Choi J. H., Kim G.Y., Seo Y.K., Kim J.C. 2001. Physical and acoustic properties of shelf sediments, the South Sea of Korea. Marine Geology, 179:39-50.

Krauskopf, K.B. 1972. Introdução à geoquímica. Polígono, São Paulo, 617pp.

Maa J.P.Y., Sun K.J., He Q. 1997. Ultrasonic characterization of marine sediments: a preliminary study. Marine Geology, 141:183-192.

Macedo H.C., Figueiredo Jr. A.G., Machado J.C. 2009. Propriedades acústicas (velocidade de propagação e coeficiente de atenuação) de sedimentos marinhos coletados nas proximidades da ilha do Cabo Frio, RJ. Revista Brasileira de Geofísica, 27(2):195-204.

Mahiques M.M., Bicego M.C., Silveira I.C.A., Sousa S.H.M., Lourenco R.A., Fukumoto M.M. 2005. Modern sedimentation in the Cabo Frio upwelling system, Southeastern Brazilian shelf. Anais da Academia Brasileira de Ciências, 77(3):535-548.

Mahiques M.M., Fukumoto M.M., Silveira I.C.A., Figueira R.C.L., Bícego M.C., Lourenço R.A., Sousa S.H.M. 2007. Sedimentary changes on the Southeastern Brazilian upper slope during the last 35,000 years. Anais da Academia Brasileira de Ciências, 79(1):171-181. 
Mahiques M.M., Mello-Sousa S.H., Furtado V.V., Tessler M.G., Toledo F.A.L., Burone L., Figueira R.C.L., Klein D.A., Martins C.C., Alves D.P.V. 2010. The southern Brazilian shelf: general characteristics, quaternary evolution and sediment distribution. Brazilian Journal of Oceanography, 58:25-34.

Mahiques M.M., Silveira I.C.A., Sousa S.H.M., Rodrigues M. 2002. Post-LGM sedimentation on the outer shelf - upper slope of the northernmost part of the São Paulo Bight, southeastern Brazil. Marine Geology, 181:387-400.

Mahiques M.M., Tessler M.G., Ciotti A.M., Silveira I.C.A., Sousa S.H.M., Figueira R.C.L., Tassinari C.C.G., Furtado V.V., Passos R.F. 2004. Hydrodynamically driven patterns of recent sedimentation in the shelf and upper slope off Southeast Brazil. Continental Shelf Research, 24:1685-1697.

Mascarenhas A.S., Miranda L.B., Rock N. 1971. A study of oceanographic conditions in the region of Cabo Frio. In: Costlow, D. Jr. (ed.) Fertility of the Sea. Gordon and Breach, New York: 285-308.

Mccave I.N. 1984. Size spectra and aggregation of suspended particles in Deep Ocean. Deep-Sea Research, 31:329-352.

Meyers P.A. 1997. Organic geochemical proxy of paleoceanographic, paleolimnologic and paleoclimatic processes. Organic Geochemistry, 27(5-6):213-250.

Meyers P.A. 2003. Applications of organic geochemistry to paleolimnological reconstructions: a summary of examples from the Laurentian Great Lakes. Organic Geochemistry, 34:261-289.

Mienert J. \& Schultheiss P. 1989. Physical properties of sedimentary environments in oceanic high (site 658) and low (site 659) productivity zones. Proceedings of the Ocean Drilling Program, Scientific Results, 108:397-406.

Moore W.S. 1984. Radium isotope measurements using germanium detectors. Nuclear Instruments and Methods, 223:407-411.

Muehe D. \& Carvalho V.G. 1993. Geomorfologia, cobertura sedimentar e transporte de sedimentos na plataforma continental interna entre a Ponta de Saquarema e o Cabo Frio (RJ). Boletim do Instituto Oceanográfico, 41:1-12.

Saavedra L., Dornelles L.M.A., Santos S.B., Absalão R., Anjos S.M.C., Melo G.V., Stanton N.S.G., Fonseca E.M., Lima L.M., Küsel E.T., Ribeiro E.O., Lazillotta A.A.A., Esteves F.A. 2009. Caracterização oceanográfica da plataforma continental interna adjacente ao Cabo Frio - RJ, no inverno de 1995. Ecologia Brasiliensis, 2:245-271.

Sanders, C.J., Caldeira, P.P., Smoak, J.M., Ketterer, M.E., Belem, A., Mendoza, U.M., Cordeiro, L.G., Silva-Filho, E.V., Patchineelam, S.R., Albuquerque, A.L.S. 2013. Recent organic carbon accumulation ( 100 years) along the Cabo Frio, Brazil upwelling region. Continental Shelf Research (submitted).

Schulz H.D. \& Zabel M. 1999. Marine Geochemistry. Second ed., SpringerVerlag Berlin Heidelberg, Germany, 582 pp.

Silveira I.C.S., Schimidt A.C.K., Campos, E.J.D., Godoi, S.S., Ikeda, Y. 2000. A corrente do Brasil ao largo da costa leste brasileira. Revista Brasileira de Oceanografia, 48(2):171-183.

Souza R.B. \& Robinson I.S. 2004. Lagrangian and satellite observations of the Brazilian Coastal Current. Continental Shelf Research, 24:241-262.

Tyson R.V. 1995. Sedimentary organic matter: organic facies and palynofacies. Chapman \& Hall, New York, 615 pp.

Valentin J.L. 1994. A ressurgência: fonte de vida nos oceanos. Ciência Hoje, 18(102):19-25. 
Valentin J.L. 1984. Analyse des paramètres hidrobiologiques dans la remontée de Cabo Frio, Brésil. Marine Biology, 82:259-273.

Wagner T., Sinninghe Damsté J.S., Hofmann P., Beckmann B. 2004. Euxinia and primary production in Late Cretaceous eastern Equatorial Atlantic surface waters fostered orbitally driven formation of marine black shales. Paleoceanography, 19:1-13.

Wakelin S. L., Holt J.T, Blackford J.C, Allen J.I., Butenschon M., Artioli Y. 2012. Modeling the carbon fluxes of the northwest European continental shelf: Validation and budgets. Journal of Geophysical Research, 117:1-17.

Wang C.W., Wang D.P., Flood R.D. 1995. Determination of environmental sensitivity of acoustic propagation on continental shelves using an equivalent fluid parabolic equation model. Journal of the Acoustical Society of America, 97(3):1596-1605. 